\title{
Investigation of climate change impacts on tourism climate comfort in Iran
}

\author{
Bakhtiari B. ${ }^{1,}{ }^{*}$ Bakhtiari A. ${ }^{2}$ and Afzali Gorouh Z. ${ }^{3}$ \\ ${ }^{1}$ Water Engineering Department, college of Agriculture, Shahid Bahonar University of Kerman, Kerman, Iran \\ 2Department of Tourism and Hospitality Management, Faculty of Tourism, Higher Education Complex of Bam, Bam, Iran \\ ${ }^{3}$ Shahid Bahonar University of Kerman, Kerman, Iran) \\ Received: 07/08/2017, Accepted: 08/02/2018, Available online: 23/05/2018 \\ *to whom all correspondence should be addressed: e-mail: drbakhtiari@uk.ac.ir
}

\begin{abstract}
In this study, Mieczkowski's Tourism Climate Index (TCl) was used for Iran to investigate the climate change impacts on outdoor human comfort. The long-term data covering a network of 153 stations were used to compute $\mathrm{TCl}$ under baseline conditions (1981-2015) and a climate change scenario (HadCM3-A1B) for 2016-2045. In this study LARSWG was used for downscaling of large spatial resolution GCM outputs to a finer spatial resolution. User-friendly and multi-platform software which is called ITCIC (Iran Tourism Climate Index Calculator) was designed to calculate $\mathrm{TCl}$. The spatial distribution of $\mathrm{TCl}$ for baseline and climate change conditions was investigated and the covered area by each $\mathrm{TCl}$ class was calculated by using ArcGIS 10. The annual distributions of $\mathrm{TCl}$ were investigated based on Scott and McBoyle (2001) Models. Also, a suite of multiple linear and non-linear regression models was used to determine the relationship between $\mathrm{TCl}$, latitudes, longitudes and elevations of regions. Root mean square error (RMSE), mean error (ME), mean absolute relative error (MARE) and coefficient of determination $\left(R^{2}\right)$ were used to evaluate the modeling accuracy. The best time and regions for outdoor activities in the base and future periods were determined. Comparison of the covered area by each $\mathrm{TCl}$ class in the base and future periods showed that the climate change occurrence was led to improving climate comfort. The results of error evaluation criteria showed that non-linear regression was appropriate for all month except January and October.
\end{abstract}

Keywords: Climate Change, Climate Comfort, Iran, Multiple Regressions, Tourism Climate Index (TCl)

\section{Introduction}

Most research on human climate comforts motivated by the potential usefulness of climatological data within planning processes for tourism and recreation. The specifications of weather and climate are not necessarily good determinates for tourism but they do establish an important factor in both financial terms, for tourism operators and tourists' experiences. Several attempts have been made to identify optimal climate conditions for tourism in general and for specific tourism activities (Mieczkowski, 1985; de Freitas, 1990; Lise and Tol, 2002; Bigano et al., 2006). Tourism climate comfort and its effect on tourists' health and activities are highly dependent on climate conditions. In this regard the growing sectors of population traveling for vacation and tourism often select their destinations according to weather and climate conditions. Statistical analyses by Maddison (2001), Lise and Tol (2002) and a simulation study by Hamilton et al., (2003) show a strong influence of climate as a factor that determines a demand for tourism. Therefore, Climate is therefore an important contraption for tourism and tourism planners need some form of information to factor it into their trip evaluation process, an index approach which can capture the multifaceted nature of weather and the complex ways in which weather variables (i.e., air temperature, relative humidity, sunshine duration, wind speed and precipitation) can be incorporated into tourism planning has been argued for (de Freitas et al., 2008). Significant effort has been devoted to preparing climate indices and several indices have been developed over the last 40 years to assess climate suitability for tourism activities (Crowe et al., 1973; Mieczkowski, 1985; Becker, 2000; Morgan et al., 2000; Maddison, 2001; Lise and Tol, 2002; Gomez Martin, 2004; Hamilton and Lau, 2005; Bigano et al., 2006; Matzarakis, 2007; de Freitas et al., 2008). Tourists and tour operators can use these climate indices to select the best time and place for a particular vacation, or plan activities appropriate to weather expectations. One of the commonly applied indices is that of Physiologically Equivalent Temperature (PET). This index evaluates thermal conditions relating to human energy balance. PET results can be presented graphically or as a bioclimatic map. Graphs mostly display the temporal behavior of PET, whereas spatial distribution is specified in bioclimatic maps (Matzarakis et al., 1999). Other possibilities are CIT (Climate Index for Tourism) (de Freitas et al., 2008) and CTIS (Climate Tourism Information Scheme) (Matzarakis, 2007; Lin and Matzarakis, 2008), both of which are based on the integration of thermal, aesthetic and physical facets of weather and climate. One of the most comprehensive schemes proposed so far is that 
of Mieczkowski (1985), who developed the 'Tourism Climate Index' (TCI). Mieczkowski's (1985) index was designed to use climate data that was already widely available for tourist destinations worldwide. The $\mathrm{TCl}$ merges seven features of climate into a single climate index. The $\mathrm{TCl}$ was originally conceptualized as a composite measure that would systematically assess the climatic elements that were most relevant to the quality of the tourist experience for the 'average' tourist (i.e., the most common tourism activities of sightseeing and shopping). $\mathrm{TCl}$ has subsequently been used in a slightly modified form by Morgan et al., (2000) for beach environments, and in a number of recent studies that assess the potential impact of global climate change on the climate resources of destinations around the world (Scott and McBoyle, 2001; Scott et al., 2003; Amelung and Viner, 2006). In Iran, several researchers analyzed and calculated $\mathrm{TCl}$. Farajzadeh and Matzarakis, (2009) computed PET and TCI in the northwest of Iran in the period 1985- 2005 from a network of 15 meteorological stations. There are a number of research about investigation of climate change impacts on tourism by using different bioclimatic indices such as (Yazdanpanah et al., 2016; Amelung et al., 2014; Amelung et al., 2007; Hamilton et al., 2005; Scott et al., 2004; Hamilton et al., 2004). Nasirihendkhaleh et al., (2014) evaluated and separated Fars province (south-central Iran) touristic climate using $\mathrm{TCl}$ and GIS framework. Esmaili and Fallah Ghalhari, (2014) evaluated the bio-climatic conditions of the tourists in Mashhad (northeast of Iran), through the use of PET index on an hourly scale. Morris et al. (2017) considered the impact of urbanization level on the interactions of the urban area, the urban climate, and human thermal comfort. Anđelković et al., (2016) proposed a new mathematical formulation of climate parameters for calculating the tourism climate comfort index (TCCl) and determined the appropriate destinations and favorable resorts for tourists in each month in Serbia. Cohen, (2013) studied the perception of human thermal sensation for Coastal Mediterranean outdoor urban environments by using a bioclimatic index. The aim of this paper is an investigation of climate change impacts on bioclimatic conditions for tourism in Iran for the baseline and future periods. In addition, this paper aimed to apply the $\mathrm{TCl}$ developed by Mieczkowski, (1985) and provide a comprehensive information source for the most suitable time periods, per region, for outdoor activities. It was the first attempt to use this index for the entire country. For this purpose, a user-friendly and multi-platform software was designed in JAVA programming language. This software is consonant with the format of Islamic Republic of Iran's Meteorological Organization (IRIMO) database. Finally, multiple regression models were used to determine the relationship between the geographic component such as latitude, longitude, elevation, and $\mathrm{TCl}$ and spatial analysis of $\mathrm{TCl}$ values.

\section{Materials and methods}

\subsection{Study area and Data}

Iran with 1648000 square kilometer area and 70 million people are one of the largest countries in the Middle East. This country is bordered to the north by the countries of Armenia, Azerbaijan and Turkmenistan and the Caspian Sea; to the east by Afghanistan and Pakistan; to the south by the Gulf of Oman and the Persian Gulf; and to the west by Iraq and Turkey. In general, Iran as a big country has a plenty of cultural (religious and pilgrimage attractions), historical and environmental (rural tourism, ecotourism and agritourism) attractions making it an area with high potential capacity for domestic and foreign tourists. Iran is one of the 10 important tourism and ecotourism destinations in the world. The topography of Iran is very complex and highly variable, resulting in diverse climatic conditions and significant variations regionally.

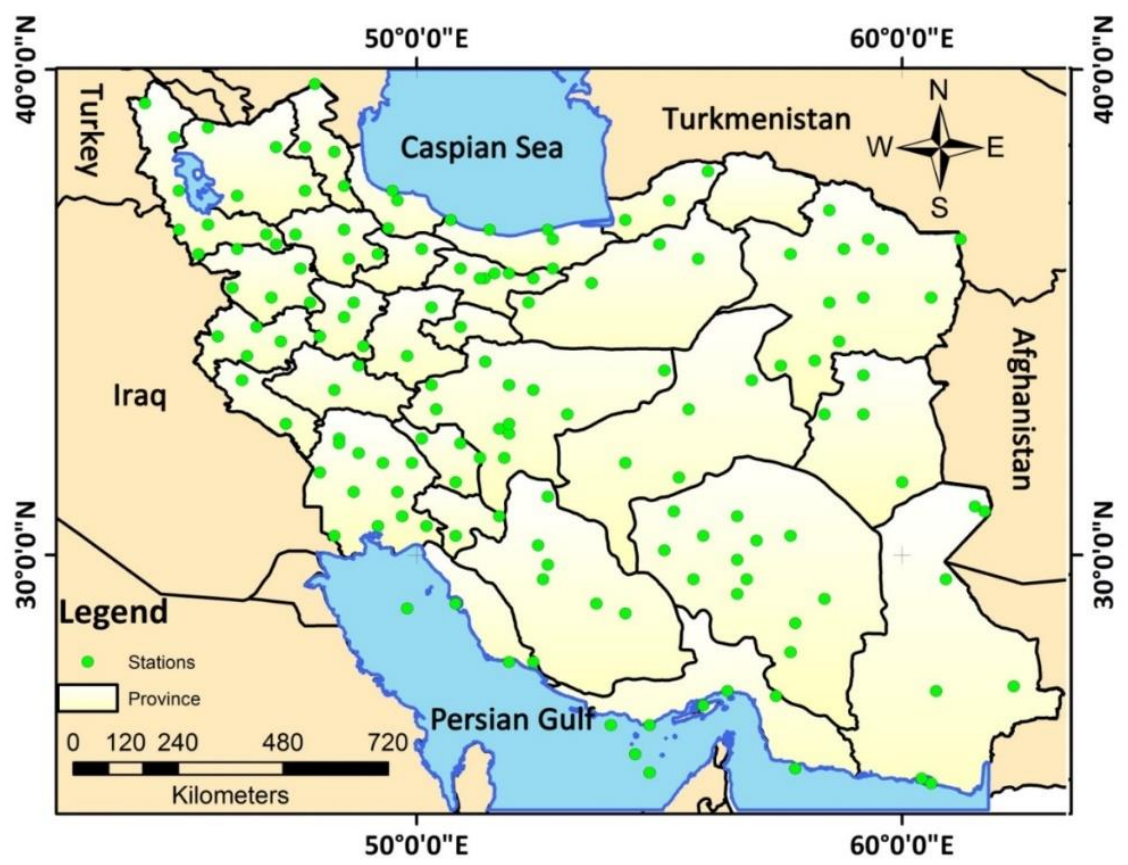

Figure 1. Study area and location of stations 
The analysis required the use of two major datasets, which contains mean monthly climate data such as dry bulb temperature (DBT), maximum daily air temperature, mean daily air temperature, minimum daily relative humidity, total precipitation, total hours of sunshine, and average wind speed for historical time period of 1981-2015 that was obtained from 153 synoptic meteorological stations of IRIMO and the general circulation model outputs under the A1B-HadCM3 scenario for the future time period of 20162045. The $A 1 B$ emissions scenario is one of the $A 1$ family scenarios that describes "a future world of very rapid economic growth, global population that peaks in midcentury and declines thereafter, and rapid introduction of new and more efficient technologies" (Setegn et al., 2011). The spatial resolution of gridded data in the HadCM3 model is $2.5^{\circ}$ latitude $\times 3.75^{\circ}$ longitude. Since general circulation models' (GCM) are coarse in resolution and are unable to resolve significant sub-grid scale features, in this study LARS-WG was used for downscaling of large spatial resolution GCM outputs to a finer spatial resolution. The procedure of calculation of $\mathrm{TCl}$ under $\mathrm{A} 1 \mathrm{~B}$ scenario is the same as the historical data sets. Figure 1 shows the spatial distribution of 153 synoptic meteorological stations considered in the analysis. These stations were located in different subclasses of arid, semi-arid, Mediterranean, semi-humid, humid, very humid $(A)$ and very humid (B) climates of Iran based on Extended-De Martonne classification (Rahimi et al. 2013).

\section{Mieczkowski's Tourism climate index}

TCl developed by Mieczkowski (1985) was based on previous research related to climate classification for tourism and recreation (Crowe, 1976). TCl consists of five sub-indices, each represented by one or two monthly climate variables. The five sub-indices and their constituent variables were as follows: (1) day time comfort index (maximum daily temperature $\left({ }^{\circ} \mathrm{C}\right.$ ) and minimum daily relative humidity (\%)), (2) daily comfort index (mean daily temperature $\left({ }^{\circ} \mathrm{C}\right.$ ) and mean daily relative humidity (\%)), (3) precipitation (total precipitation, $(\mathrm{mm})$ ), (4) sunshine (total hours of sunshine), and (5) wind (average wind speed $\left(\mathrm{m} \mathrm{s}^{-1}\right.$ or $\left.\mathrm{km} \mathrm{h}^{-1}\right)$. Equation 1 represents the index.

$$
\mathrm{TCl}=2 \times(4 \times \mathrm{CID}+\mathrm{ClA}+2 \times \mathrm{R}+2 \times \mathrm{S}+\mathrm{W})
$$

Where Cld is daytime comfort index consisting of the mean maximum air temperature $\left({ }^{\circ} \mathrm{C}\right)$ and the mean minimum relative humidity (\%), Cla the daily comfort index consisting of the mean air temperature $\left({ }^{\circ} \mathrm{C}\right)$ and the mean relative humidity (\%), R is precipitation $(\mathrm{mm}), S$ is daily sunshine duration ( $\mathrm{hr}$ ) and $\mathrm{W}$ is the mean wind Speed $\left(\mathrm{m} \mathrm{s}^{-1}\right)$.

In the equation proposed by Mieczkowski, the highest weight is given to the daytime comfort index to reflect the fact that tourists are generally most active during the day. The amount of sunshine and the amount of precipitation are given the second highest weights, followed by daily thermal comfort and wind speed. With an optimal rating for each variable of 5.0, the maximum value of the index was 100 . Based on each location's index value, its suitability for tourism activity was then rated on a scale from -30 to 100. Mieczkowski, (1985) divided this scale into 10 categories, ranging from ideal (90-100), excellent (80-89), and very good (70-79) to extremely unfavorable (10-19) and impossible (9 to -30 ) (Table 1$)$.

Table 1. Rating categories in tourism climate index Mieczkowski (1985)

\begin{tabular}{cccc}
\hline TCl score & Code & Descriptive Category & Mapping Category \\
\hline $90<\mathrm{TCl}<100$ & 9 & Ideal & Excellent \\
$80<\mathrm{TCl}<89.9$ & 8 & Excellent & Very good and Good \\
$70<\mathrm{TCl}<79.9$ & 7 & Very good & Acceptable \\
$60<\mathrm{TCl}<69.9$ & 6 & Good & \\
$50<\mathrm{TCl}<59.9$ & 5 & Acceptable & Unfavorable \\
$40<\mathrm{TCl}<49.9$ & 4 & Marginal & \\
$30<\mathrm{TCl}<39.9$ & 3 & Unfavorable & \\
$20<\mathrm{TCl}<29.9$ & 2 & Very unfavorable & \\
$10<\mathrm{TCl}<19.9$ & 1 & Impossible & \\
$-20<\mathrm{TCl}<9.9$ & 0 & &
\end{tabular}

\section{Scott and McBoyle (2001) Models}

Scott and McBoyle (2001) proposed that the climate could be classified for each tourist destination into one of six annual distributions. If $\mathrm{TCl} \geq 80$ for each month of the year, Tourism climate typology in the model is an 'optimal'. If TCI $<40$ throughout the year it suggests a 'poor' year-round tourism climate. The peak curves for 'summer' and 'winter peak' were similar and outstanding by season in which more suitable climatic conditions occurred. A 'summer peak' corresponds to amid- to high latitude locations where summer was considered as the most pleasant period of the year for tourism activity. A 'winter peak' would occur in the lower-latitude locations where cooler and/or lower humidity conditions in winter make conditions more comfortable for tourists compared to hot and/or humid summer weather. Where spring and fall months were more suitable for tourist activity a 'bimodal' or 'shoulder peak' distribution was shown. The tourism climate resources in regions with separate wet and dry seasons were mostly dependent on precipitation. The $\mathrm{TCl}$ in these regions displayed a dry season peak when the climate was most conducive to tourism activity (Scott et al., 2004). 


\section{Software development for Iran's TCl calculations}

\section{Effective Temperature Index calculation}

Psychrometric charts are very important in many respects such as the design of air conditioning systems and human comfort. These calculations account for the relationships inter depending dry and wet bulb temperatures, relative humidity, enthalpy and specific volume. In Mieczkowski's index, Cla (daily comfort index) and Cid (daytime comfort index) are considered as comfort indicators that their levels are obtained from the psychrometric diagram which ASHRAE (American Society of Heating, Refrigerating and Air Conditioning Engineers) thermal comfort standard has been drawn. According to a definition of ASHRAE, thermal comfort is the intellectual condition that can be expressed satisfaction with the environment. According to ASHRAE (1972), thermal zone forms the optimal zone for the $\mathrm{TCl}$, with a rating of 5.0 points. The rating scale then decreases gradually on both sides of the optimal zone, according to an ideal assigned set of sequential values. The boundaries between the rating zones are the effective temperature lines derived from the ASHRAE comfort chart. In this study, because of a high volume of data and required calculations, authors decided to extract the equations of lines and curves of ASHRAE comfort chart by the set of points. Then a short program was written in Excel software and the rating of $\mathrm{Cla}$ and $\mathrm{Cld}$ were determined for each month in studying stations. Figure 2 shows the output of the program for determination of $\mathrm{Cld}$ and Cla rates of Shiraz station.
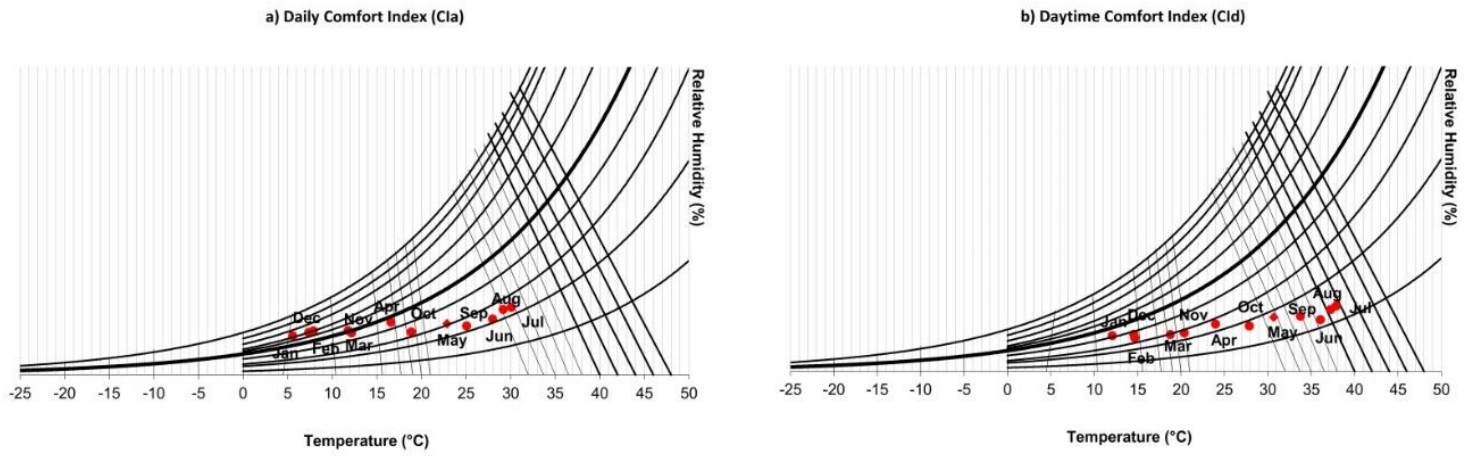

Figure 2. (a) Cla (daily comfort index) and (b) Cld (daytime comfort index) for months of a year in Shiraz station

\section{Software presentation for Iran's TCI evaluation}

In order to assess climate comfort range for tourism planning in Iran, weather and climatic data in synoptic stations obtained from IRIMO are used in TCI computation. The proposed software (ITCIC) provides various situations in tourism management and hospitality. This is userfriendly and multi-platform software that supported Windows, Linux and Macintosh OS X operating systems and developed using JAVA language. The JAVA files are in Notepad format (HTML. format). The program accesses the required data files and converts them to Excel files and saves them automatically on the same drive. The program is set up to omit the years with incomplete weather data

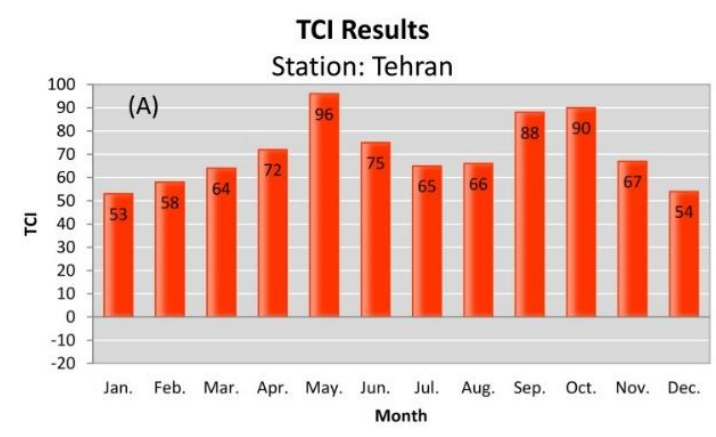

and then calculate the $\mathrm{TCl}$ monthly normal climatic variables. The calculated climatic normal information for each station include, maximum and mean daily temperature, minimum and mean daily relative humidity. This information is then transferred to ASHRAE effective temperature Chart and the rating of $\mathrm{Cla}$ and $\mathrm{Cid}$ are determined for each month separately (Figure 2). The TCI values are calculated and categorized by the program is imported to the display window (Figure 3). The point of interest here is to determine the rank of the wind speed. This variable is an intangible factor to evaluate the TCl. Four distinct wind rating schemes were proposed by Mieczkowski, (1985).

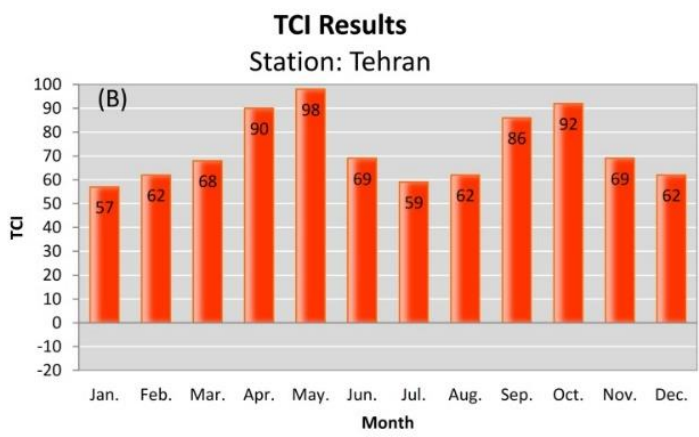

Figure 3. (A) TCI results in the base period (1951-2015), (B) TCI results in the future period (2016-2046)

They include the normal system, trade wind system; hot climate system and wind chill cooling rates. The rating of normal, trade wind and hot climate systems could be proposed based on Mieczkowski's table and converted into 
the computer code. However, if the months in which the mean daily maximum temperature is less than $15^{\circ} \mathrm{C}$ and the mean wind speed is greater than $8 \mathrm{~km} \mathrm{~h}^{-1}$, a wind chill nomogram prepared by Canada is used (Mieczkowski, 1985). If these conditions occur in a month, a window automatically opens and requests the wind rate. Otherwise, by running the program and call the desired stations file, a window will open and requests the $\mathrm{Cla}$ and Cld values for each month. As it is shown in Figure 3, the final outputs of this program are given in graphic and table forms for each station.

\section{Regression model}

In this study, multiple regression models were used for spatial analysis of $\mathrm{TCl}$ values and determining the relationship between the geographic component such as latitude, longitude, elevation, and $\mathrm{TCl}$. Therefore, for determining the best regression model, the calculated $\mathrm{TCl}$ values by mentioned software for each month in a year were used as dependent variable and geographic parameters such as latitude, longitude, elevation above the sea level in 153 stations were used as independent variables. Multiple regression analysis was performed using stepwise and enter modes. Any correlations of 0.7 or above between independent variables suggest that Multicollinearity is a potential problem. A common statistic is the tolerance index. Multicollinearity is likely to be problematic when it is low (Baggio and Klobas, 2011). To quantify the effects of the geographical coordinates on $\mathrm{TCl}$, analysis of variance of the linear regressions were performed using the $\mathrm{F}$ test at $95 \%$ confidence level. The Kolmogorov-Smirnov and Durbin-Watson tests were used to verify whether they presented, a normal distribution, and errors independence, respectively (Bosco et al., 2015). The modeling accuracy was assessed by the root mean square error (RMSE), mean error (ME), mean absolute relative error (MARE) and coefficient of determination $\left(R^{2}\right)$ and can be calculated by equations 2 to 5 (Liu, 2014; Moffat et al., 2007).

$$
\begin{aligned}
& \text { RMSE }=\sqrt{\frac{\sum_{i=1}^{n}\left(\mathrm{TCl}_{\mathrm{o}}-\mathrm{TCl}_{\mathrm{p}}\right)^{2}}{\mathrm{n}}} \\
& \mathrm{ME}=\frac{\sum_{\mathrm{i}=1}^{\mathrm{n}}\left(\mathrm{TCl}_{\mathrm{p}}-\mathrm{TCl}_{\mathrm{o}}\right)}{\mathrm{n}} \\
& \text { MARE }=\frac{1}{\mathrm{n}} \sum_{\mathrm{i}=1}^{\mathrm{n}} \frac{\left|\mathrm{TCl}_{\mathrm{o}}-\mathrm{TCl}_{\mathrm{p}}\right|}{\mathrm{TCl}} \\
& \mathrm{R}^{2}=1-\frac{\sum_{\mathrm{i}=1}^{n}\left[\mathrm{TCl}_{\mathrm{o}}-\mathrm{TCl}_{\mathrm{p}}\right]^{2}}{\sum_{\mathrm{i}=1}^{n}\left[\mathrm{TCl}_{\mathrm{o}}-\mathrm{TCl}_{\mathrm{o}}\right]^{2}}
\end{aligned}
$$

Where, $\mathrm{TCl}_{\mathrm{p}} \mathrm{TCl}_{\mathrm{o}}$ and $\overline{\mathrm{TCl}_{\mathrm{o}}}$ are the calculated $\mathrm{TCl}$ values by regression models, the obtained values by main model and average of the obtained values by main model, respectively and $\mathrm{n}$ is the number of samples.

\section{Results and Discussion}

Since Iran is an attractive tourist destination, human climate comfort indicators will be useful for travel planning. Using ITCTC program, Iran's climatic data were used to calculate monthly climate indices. Some of the results are provided as an example. Table 2 shows the monthly TCl values for the base (1981-2015) and future (2016-2045) periods in Tehran station. This information can be classified into one of six annual TCl distributions. Based

\begin{tabular}{|c|c|c|c|c|c|c|c|c|c|}
\hline Station & \multicolumn{4}{|c|}{ Tehran } & Station & \multicolumn{4}{|c|}{ Tehran } \\
\hline Code & \multicolumn{4}{|c|}{40754} & Code & \multicolumn{4}{|c|}{40754} \\
\hline Latitude & \multicolumn{4}{|c|}{$3541 \mathrm{~N}$} & Latitude & \multicolumn{4}{|c|}{$3541 \mathrm{~N}$} \\
\hline Longitude & \multicolumn{4}{|c|}{$5119 \mathrm{E}$} & Longitude & \multicolumn{4}{|c|}{$5119 \mathrm{E}$} \\
\hline $\begin{array}{l}\text { Elevation } \\
\text { Period }\end{array}$ & \multicolumn{4}{|c|}{$\begin{array}{l}1190.8 \mathrm{M} \\
\text { baseline (1981-2015) }\end{array}$} & $\begin{array}{l}\text { Elevation } \\
\text { period }\end{array}$ & \multicolumn{4}{|c|}{$\begin{array}{l}1190.8 \mathrm{M} \\
\text { future (2016-2045) }\end{array}$} \\
\hline Month & $\mathrm{TCl}$ & Code & $\begin{array}{c}\text { Descriptive } \\
\text { category }\end{array}$ & Mapping category & Month & $\mathrm{TCl}$ & Code & $\begin{array}{c}\text { Descriptive } \\
\text { category }\end{array}$ & $\begin{array}{l}\text { Mapping } \\
\text { category }\end{array}$ \\
\hline Jan. & 53 & 5 & Acceptable & Acceptable & Jan. & 57 & 5 & acceptable & acceptable \\
\hline Feb. & 58 & 5 & Acceptable & Acceptable & Feb. & 62 & 6 & good & very good \& good \\
\hline Mar. & 64 & 6 & Good & Very Good \& Good & Mar. & 68 & 6 & good & very good \& good \\
\hline Apr. & 72 & 7 & Very Good & Very Good \& Good & Apr. & 90 & 9 & Ideal & excellent \\
\hline May. & 96 & 9 & Ideal & Excellent & May. & 98 & 9 & Ideal & excellent \\
\hline Jun. & 75 & 7 & Very Good & Very Good \& Good & Jun. & 69 & 6 & good & very good \& good \\
\hline Jul. & 65 & 6 & Good & Very Good \& Good & Jul. & 59 & 5 & acceptable & acceptable \\
\hline Aug. & 66 & 6 & Good & Very Good \& Good & Aug. & 62 & 6 & good & acceptable \\
\hline Sep. & 88 & 8 & Excellent & Excellent & Sep. & 86 & 8 & Excellent & very good \& good \\
\hline Oct. & 90 & 9 & Ideal & Excellent & Oct. & 92 & 9 & ideal & excellent \\
\hline Nov. & 67 & 6 & Good & Acceptable & Nov. & 69 & 6 & good & very good \& good \\
\hline Dec. & 54 & 4 & Acceptable & Acceptable & Dec. & 62 & 6 & good & very good \& good \\
\hline
\end{tabular}
on the results of this study, the model for 153 synoptic weather stations had been determined.

Table 2. Monthly $\mathrm{TCl}$ values, descriptive and mapping category as output ITCTC software for Tehran station

Table 3 shows the Scott and McBoyle, (2001) models based on monthly $\mathrm{TCl}$ changes in Iran's province centers. In baseline and future periods 24 provinces were found to be bimodal-shoulder peaks. In these areas spring and autumn seasons were determined as having a comfortable climate for tourism activity, especially for ecotourism and agritourism. In these cities, the heat made the summer climate uncomfortable for tourists while winters were considered cool. Four provinces had summer peak and one of them had winter peak distribution. None of the stations were followed by an optimal, dry season peak or a weak distribution. Spatial distributions of $\mathrm{TCl}$ for all months in 
baseline and future periods were investigated by using ArcGIS ver.10 software and Kriging method of Interpolation. The most suitable areas and months for

Table 3. TCl score and its annual distribution in Iran's province centers for baseline (1981-2015) and future (2016-2045) periods

\begin{tabular}{|c|c|c|c|c|c|c|c|c|c|c|c|c|c|c|}
\hline Station & Period & Jan. & Feb. & Mar. & Apr. & May. & Jun. & Jul. & Aug. & Sep. & Oct. & Nov. & Dec. & Annual TCl distribution \\
\hline \multirow{2}{*}{ Ahvaz } & Baseline & 65 & 79 & 84 & 78 & 58 & 44 & 43 & 44 & 52 & 64 & 83 & 73 & Bimodal Peaks \\
\hline & Future & 77 & 88 & 96 & 69 & 41 & 42 & 43 & 43 & 44 & 62 & 90 & 84 & Bimodal Peaks \\
\hline \multirow{2}{*}{ Arak } & Baseline & 37 & 44 & 58 & 73 & 89 & 88 & 72 & 76 & 91 & 91 & 61 & 52 & Bimodal Peaks \\
\hline & Future & 50 & 53 & 63 & 68 & 80 & 90 & 86 & 88 & 87 & 72 & 60 & 51 & Bimodal Peaks \\
\hline \multirow{2}{*}{ Ardabil } & Baseline & 42 & 44 & 49 & 62 & 77 & 88 & 96 & 92 & 88 & 67 & 51 & 47 & Summer peak \\
\hline & Future & 50 & 54 & 59 & 67 & 87 & 96 & 96 & 96 & 86 & 76 & 60 & 52 & Summer peak \\
\hline \multirow{2}{*}{ BandarAbbas } & Baseline & 85 & 85 & 84 & 73 & 49 & 42 & 36 & 36 & 39 & 53 & 80 & 85 & Winter Peak \\
\hline & Future & 90 & 94 & 88 & 58 & 43 & 39 & 46 & 46 & 37 & 49 & 76 & 90 & Winter Peak \\
\hline \multirow{2}{*}{ Birjand } & Baseline & 61 & 60 & 76 & 87 & 92 & 74 & 70 & 74 & 92 & 91 & 76 & 63 & Bimodal Peaks \\
\hline & Future & 65 & 64 & 78 & 92 & 92 & 91 & 84 & 84 & 92 & 90 & 79 & 66 & Bimodal Peaks \\
\hline \multirow{2}{*}{ Bojnurd } & Baseline & 54 & 55 & 56 & 76 & 89 & 94 & 84 & 86 & 94 & 87 & 61 & 54 & Summer peak \\
\hline & Future & 60 & 63 & 77 & 88 & 84 & 95 & 84 & 89 & 89 & 91 & 76 & 61 & Summer peak \\
\hline \multirow{2}{*}{ Bushehr } & Baseline & 66 & 76 & 87 & 72 & 62 & 49 & 44 & 43 & 48 & 68 & 88 & 75 & Bimodal Peaks \\
\hline & Future & 74 & 85 & 90 & 76 & 56 & 49 & 42 & 47 & 47 & 69 & 89 & 83 & Bimodal Peaks \\
\hline \multirow{2}{*}{ Esfahan } & Baseline & 58 & 66 & 68 & 87 & 96 & 80 & 71 & 72 & 87 & 89 & 71 & 63 & Bimodal Peaks \\
\hline & Future & 78 & 88 & 92 & 88 & 61 & 62 & 60 & 52 & 60 & 75 & 89 & 87 & Bimodal Peaks \\
\hline \multirow{2}{*}{ Ghazvin } & Baseline & 54 & 53 & 58 & 77 & 86 & 84 & 70 & 70 & 92 & 84 & 57 & 48 & Bimodal Peaks \\
\hline & Future & 57 & 59 & 68 & 87 & 92 & 76 & 66 & 66 & 88 & 88 & 65 & 58 & Bimodal Peaks \\
\hline \multirow{2}{*}{ Ghom } & Baseline & 62 & 62 & 73 & 88 & 88 & 66 & 56 & 60 & 71 & 89 & 73 & 60 & Bimodal Peaks \\
\hline & Future & 60 & 66 & 87 & 94 & 73 & 61 & 49 & 54 & 74 & 89 & 78 & 63 & Bimodal Peaks \\
\hline \multirow{2}{*}{ Gorgan } & Baseline & 55 & 55 & 58 & 79 & 83 & 71 & 60 & 60 & 67 & 78 & 78 & 56 & Bimodal Peaks \\
\hline & Future & 64 & 61 & 68 & 85 & 81 & 61 & 51 & 55 & 69 & 86 & 77 & 62 & Bimodal Peaks \\
\hline \multirow{2}{*}{ Hamedan } & Baseline & 47 & 48 & 55 & 70 & 90 & 91 & 77 & 77 & 94 & 88 & 59 & 50 & Summer peak \\
\hline & Future & 50 & 56 & 64 & 77 & 96 & 92 & 66 & 74 & 90 & 87 & 60 & 48 & Summer peak \\
\hline Ham & Baseline & 42 & 49 & 48 & 79 & 96 & 90 & 70 & 70 & 92 & 82 & 61 & 51 & Bimodal Peaks \\
\hline $11 \mathrm{am}$ & Future & 58 & 64 & 71 & 88 & 94 & 73 & 61 & 64 & 88 & 90 & 70 & 63 & Bimodal Peaks \\
\hline Karai & Baseline & 55 & 53 & 56 & 83 & 94 & 86 & 70 & 71 & 84 & 91 & 63 & 43 & Bimodal Peaks \\
\hline Kard] & Future & 56 & 58 & 68 & 87 & 98 & 75 & 65 & 66 & 88 & 88 & 64 & 57 & Bimodal Peaks \\
\hline Kerman & Baseline & 59 & 60 & 73 & 90 & 94 & 74 & 70 & 74 & 94 & 91 & 77 & 62 & Bimodal Peaks \\
\hline Kerman & Future & 62 & 69 & 87 & 94 & 74 & 64 & 62 & 74 & 75 & 90 & 89 & 70 & Bimodal Peaks \\
\hline Kermanshah & Baseline & 47 & 49 & 50 & 74 & 86 & 79 & 67 & 67 & 76 & 87 & 63 & 47 & Bimodal Peaks \\
\hline kermanstian & Future & 57 & 60 & 67 & 84 & 88 & 67 & 57 & 58 & 76 & 88 & 69 & 62 & Bimodal Peaks \\
\hline Khorramabad & Baseline & 48 & 57 & 56 & 80 & 92 & 72 & 63 & 63 & 76 & 87 & 72 & 53 & Bimodal Peaks \\
\hline Knorramada & Future & 62 & 64 & 79 & 88 & 86 & 68 & 56 & 56 & 76 & 89 & 78 & 63 & Bimodal Peaks \\
\hline Mashbad & Baseline & 52 & 53 & 52 & 79 & 91 & 86 & 71 & 76 & 95 & 87 & 67 & 54 & Bimodal Peaks \\
\hline IVIasnnaa & Future & 56 & 62 & 67 & 90 & 94 & 73 & 63 & 74 & 88 & 90 & 69 & 61 & Bimodal Peaks \\
\hline Oroomieh & Baseline & 47 & 51 & 51 & 63 & 84 & 96 & 88 & 88 & 94 & 82 & 59 & 54 & Bimodal Peaks \\
\hline Uroomien & Future & 51 & 57 & 65 & 71 & 92 & 88 & 79 & 79 & 93 & 88 & 63 & 55 & Bimodal Peaks \\
\hline Rasht & Baseline & 39 & 43 & 43 & 70 & 82 & 77 & 64 & 54 & 55 & 63 & 48 & 37 & Bimodal Peaks \\
\hline nastil & Future & 57 & 59 & 60 & 83 & 87 & 73 & 65 & 61 & 75 & 85 & 64 & 57 & Bimodal Peaks \\
\hline Sanandai & Baseline & 45 & 46 & 45 & 62 & 84 & 87 & 72 & 72 & 90 & 84 & 63 & 50 & Bimodal Peaks \\
\hline Sallatiuaj & Future & 57 & 59 & 70 & 86 & 92 & 76 & 64 & 66 & 88 & 88 & 69 & 60 & Bimodal Peaks \\
\hline Semnan & Baseline & 57 & 63 & 68 & 87 & 90 & 71 & 61 & 66 & 84 & 90 & 74 & 62 & Bimodal Peaks \\
\hline semnan & Future & 61 & 67 & 80 & 90 & 88 & 62 & 52 & 55 & 72 & 91 & 70 & 64 & Bimodal Peaks \\
\hline Shahrekord & Baseline & 46 & 58 & 58 & 71 & 90 & 91 & 77 & 81 & 94 & 90 & 63 & 52 & Bimodal Peaks \\
\hline & Future & 56 & 62 & 68 & 81 & 92 & 87 & 77 & 74 & 93 & 90 & 67 & 60 & Bimodal Peaks \\
\hline Shiraz & Baseline & 54 & 60 & 72 & 88 & 94 & 71 & 66 & 67 & 80 & 92 & 83 & 58 & Bimodal Peaks \\
\hline sniraz & Future & 64 & 68 & 87 & 96 & 92 & 64 & 52 & 62 & 74 & 96 & 77 & 68 & Bimodal Peaks \\
\hline Tehran & Baseline & 54 & 58 & 63 & 84 & 96 & 75 & 65 & 71 & 88 & 90 & 67 & 58 & Bimodal Peaks \\
\hline lenran & Future & 57 & 62 & 68 & 90 & 98 & 69 & 59 & 62 & 86 & 92 & 69 & 62 & Bimodal Peaks \\
\hline Yасиі & Baseline & 38 & 40 & 44 & 81 & 91 & 87 & 76 & 77 & 91 & 89 & 65 & 45 & Bimodal Peaks \\
\hline rasuj & Future & 60 & 67 & 71 & 89 & 95 & 77 & 66 & 77 & 87 & 89 & 72 & 65 & Bimodal Peaks \\
\hline Yazd & Baseline & 64 & 66 & 80 & 93 & 88 & 66 & 59 & 59 & 76 & 93 & 83 & 64 & Bimodal Peaks \\
\hline Yaza & Future & 64 & 66 & 89 & 98 & 73 & 61 & 49 & 61 & 74 & 94 & 79 & 66 & Bimodal Peaks \\
\hline 7ahedan & Baseline & 60 & 66 & 85 & 95 & 88 & 66 & 63 & 67 & 88 & 91 & 89 & 69 & Bimodal Peaks \\
\hline Lanedan & Future & 66 & 81 & 88 & 94 & 89 & 75 & 63 & 65 & 75 & 96 & 89 & 70 & Bimodal Peaks \\
\hline & Baseline & 48 & 45 & 53 & 68 & 86 & 96 & 86 & 86 & 94 & 81 & 58 & 48 & Summer peak \\
\hline गJan & Future & 51 & 57 & 65 & 72 & 93 & 87 & 79 & 79 & 93 & 88 & 63 & 55 & Summer peak \\
\hline
\end{tabular}

\section{Baseline Period (1981- 2015)}

The spatial distribution of $\mathrm{TCl}$ over the study area in baseline period is showed in Figure 4. The covered area by each $\mathrm{TCl}$ classes was calculated by using ArcGIS software. tourism activities were determined and are shown with 24 maps for two periods in Figures 4 and 5, respectively. 
of the total area have TCl values 40-50 in "Marginal class". $35.91 \%$ of total area in central has "Acceptable" condition. The corresponding area for "Good", "Very Good", and "Excellent" are "38.92\%", "7.63\%", and "0.93\%", respectively. In February, the northwestern parts of Iran (include East and West Azerbaijan provinces, Gilan, Hamedan, Kurdistan, and Kermanshah) with $10.8 \%$ of total area, experienced "marginal" climate conditions. The climatic conditions have ascending trend from west to east. The provinces such as Mazandaran, Zanjan, Qazvin, Alborz, Tehran, Qom, Markazi, Lorestan, Chaharmahan and Bakhtiari, Kohgiloyeh and Boyer Ahmad, west of Isfahan, west and north of Fars were located in "Acceptable" class with $26.9 \%$ of total area. $39.8 \%$ of Iran's area include North Khorasan, Razavi Khorasan, western parts of South Khorasan, Yazd, north of Kerman, south of Fars, and Khuzestan have "Good" climate condition. The southeastern parts of Iran have "Very Good" climate conditions. In March the $\mathrm{TCl}$ values have ascending trend from northwest to southeast. So that the most appropriate destinations were located in southeastern parts of the country, and the northwestern area has acceptable conditions. Based on Figure 4, Sistan and Baluchestan have "Excellent" and "Ideal" conditions for outdoor activities.
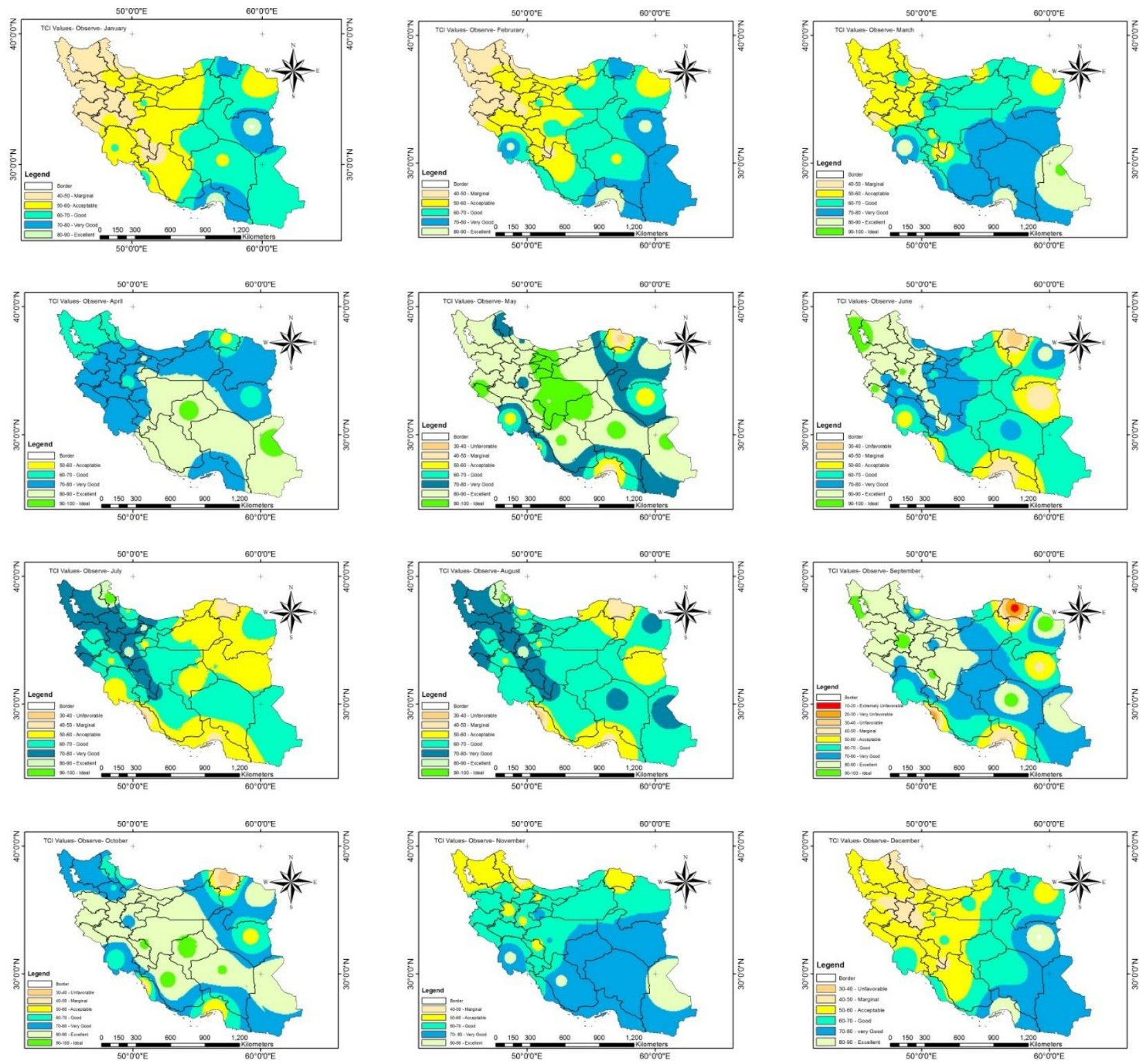

Figure 4. Spatial distribution of Tourism Climate Index over the study area in the base period (1981-2015)

The results of $\mathrm{TCl}$ showed that in April, the largest area is related to "Very Good" class located in the northeast, north, south, and western parts with $55.3 \%$ of total area. The provinces of Isfahan, Yazd, Kerman, Sistan and Baluchestan, Fars and Bushehr with about 31.65\% area have the "Excellent" condition for outdoor activities. Northwestern parts of the country and North Khorasan (about 11\%) is located in "Good" class. The variation of TCl index in May indicated that in this time tourist can be selected various destinations based on own preferences. In this time the most appropriate destinations are Mazandaran, Tehran, Alborz, Isfahan, and Yazd provinces, while North Khorasan and Homozgan province have "Marginal" and "Unfavorable" conditions. In the month of June during baseline period, $46.64 \%$ of the country has the "Good" condition that this area was covered central parts 
of Iran. The provinces of North Khorasan, South Khorasan, Hormozgan, and Bushehr have inappropriate conditions for outdoor activities. In the month of July, $\mathrm{TCl}$ scores were divided into 7 classes include "Ideal", "Excellent", "Very good", "Good", "Acceptable", "Marginal", and "Unfavorable". Due to the distribution of $\mathrm{TCl}$ scores on Figure 4, it can be noted that the "Good" class has the largest area (43.32\%). The "Acceptable" category was covered $39.66 \%$ of total Iran's area. $0.11 \%$ of Iran's area was covered by "Unfavorable" condition that this category was eliminated in the future period, for improving climate conditions under climate change conditions. In the middle of summer (August), Iran's climatic conditions were divided into 7 classes such as "Ideal", "Excellent", "Very Good", "Good", "Acceptable", "Marginal", and "Unfavorable". The climatic condition $60.73 \%$ of total Iran's area was situated in "Good" class. Ardabil province, that is located in the west of Caspian Sea, has the highest amount of $\mathrm{TCl}$ and Ideal conditions for tourism activities.

In September, $41.16 \%$ of the country including "parts of Sistan and Baluchestan, Kerman, Yazd, Fars, Khuzestan, Semnan, Mazandaran, and Gilan provinces" has "Very Good" climatic condition. Due to $\mathrm{TCl}$ values, $4.74 \%$ of the country does not have appropriate conditions for tourism activities. In the beginning autumn (October), the highest area of the country (51.09\%) have "Good" climatic condition, while 0.88 and $0.41 \%$ of the country have "Marginal" and "Unfavorable" climatic condition. In total, $98.7 \%$ of the country has appropriate conditions for tourism activities. $\mathrm{TCl}$ value in November was in the range of 31 and 96 . The $\mathrm{TCl}$ values increased from northwest to southeast. The 44.9 and $39.24 \%$ of the country was situated in "Good" and "Very Good" classes. In the first priority the northern parts of Sistan and Baluchestan (4.77\% of the country) have "Excellent" condition; in the second priority the southern parts of Razavi Khorasan, South Khorasan, Yazd, Kerman, Hormozgan, Fars, and Khuzestan provinces (39.24\%) have "Very Good" condition. The central, northeastern, western, and southwestern parts of country $(44.9 \%)$ have "Good" condition and were situated in third priority. The northwestern parts of country and North Khorasan (10.92 \%) have "Acceptable" climatic condition. Therefore, the $99.8 \%$ of the country have an appropriate condition for outdoor activities. In the latest month of the year, December, the northern, western, and central parts of the country (37.12\%) was located in "Acceptable", while the northeastern ,southern, and eastern parts of country were located in "Excellent", "Very Good", and "Good" with 2.51, 22.85, and $31.61 \%$ of Country. The 5.83 and $0.08 \%$ of the country has "Marginal" and "Unfavorable" climatic conditions. The amount of TCl increased from northwest to southeast. In this study, the results of $\mathrm{TCl}$ and annual $\mathrm{TCl}$ distribution in northwest of Iran (such as Ahar, Parsabad, Ardabil, Sagez, Jolfa, Sanandaj, Khoy, Sarab, Mahabad, Tabriz, Maku, Takab, Marageh, Zanjan and Ourmieh) are consistent with the general results of Farajzadeh and Matzarakis (2009). In both studies Makoo, Ahar, Ardabil, Khoy, Sarab, Takab, and Ourmieh had summer peak distribution and ParsabadMoghan and Jolfa had bimodal-shoulder peak.
Based on the results of Gangomkar and Mohseni (2011) over the Mazandaran Province in the northern parts of Iran, the best time for tourism and outdoor activities is June. In the second preference May, July, August and September were suitable. While the results of this study showed that May and October with $\mathrm{TCl}$ values (80-100) had Excellent and ideal condition. Also, April, June, July and September with TCl values (60-80) had Very good and good conditions. It seems the difference might be related to the difference in length of input data, impact of climate change and recent year's data on average of climatic data.

\section{Future Period (2016- 2045)}

The Spatial distribution of $\mathrm{TCl}$ over the study area in the future period under A1B scenario is shown in Figure 5. The results of A1B Scenario in January showed that based on $\mathrm{TCl}$ values Iran's climatic conditions were divided into 4 parts such as "Acceptable", "Good", "Very Good", and "Excellent". The northwestern and northeastern parts of Iran (29\% Iran's area) will have experienced "Acceptable" climatic condition. Owing to the conformity of January with autumn and winter seasons, it was expected that the hot and dry areas have better conditions for tourism activities in Iran. Therefore $\mathbf{1 . 8 9} \%$ of Iran's area has "Excellent" climatic condition, $7.9 \%$ has "Very Good" climatic condition, and $61.21 \%$ has "Good" climatic condition. Comparison of the results of this month in baseline and future periods showed that the climatic condition was improved for tourism activities. Based on the A1B scenario, in the second month of the year, February, the northwestern parts of Iran with Areas of $13.15 \%$ will have experienced "Acceptable" climatic condition. The northern and central parts of the country (about $45.82 \%$ of total area) have $\mathrm{TCl}$ values $60-70$ with "Good" climatic conditions.

The major parts of some provinces such as Kerman, Sistan and Baluchestan, Fars, Bushehr, and Khuzestan have "Very Good" climatic condition that included in $34.64 \%$ of the total country area. Among all destinations, the southern coastal area such as Khuzestan, Bushehr, Sistan and Baluchestan, and Hormozgan province have "Excellent" and "Ideal" conditions for tourism activities in February. Being located near the sea to cause this area has best climatic conditions in winter. Comparison of the results of baseline and future periods indicated that occurrence of climate change led to improving the climatic conditions for outdoor activities. So that with eliminating "Marginal" class in the baseline period, future condition shifted right and creates "ideal" class.

In the future period, under climate change impacts, the month of March have conformity with late winter and early spring season. With starting the spring season, it was expected that the climatic conditions get better for outdoor activities in Iran.

The climatic conditions divided into 5 classes such as "Ideal", "Excellent", "Very Good", "Good", and "Acceptable". The northwestern part of Iran (about 17.3\% of Iran's area), such as "West Azerbaijan", "East Azerbaijan", "Ardabil”, "Zanjan", "Hamedan", “Qazvin", 
"Kermanshah", "Markazi", "Alborz" and parts of Mazandaran, Tehran, and Razavi Khorasan province that have cold climate, will have experienced "Good" climatic condition. Some provinces such as llam, Lorestan, north of Isfahan, Kohgiloyeh and Boyerahmad, Chaharmahal and Bakhtiari, Semnan, North Khorasan, Razavi Khorasan, northern parts of South Khorasan, and north of Fars will have located in "Very Good" classes (about 38.6\% of Iran's
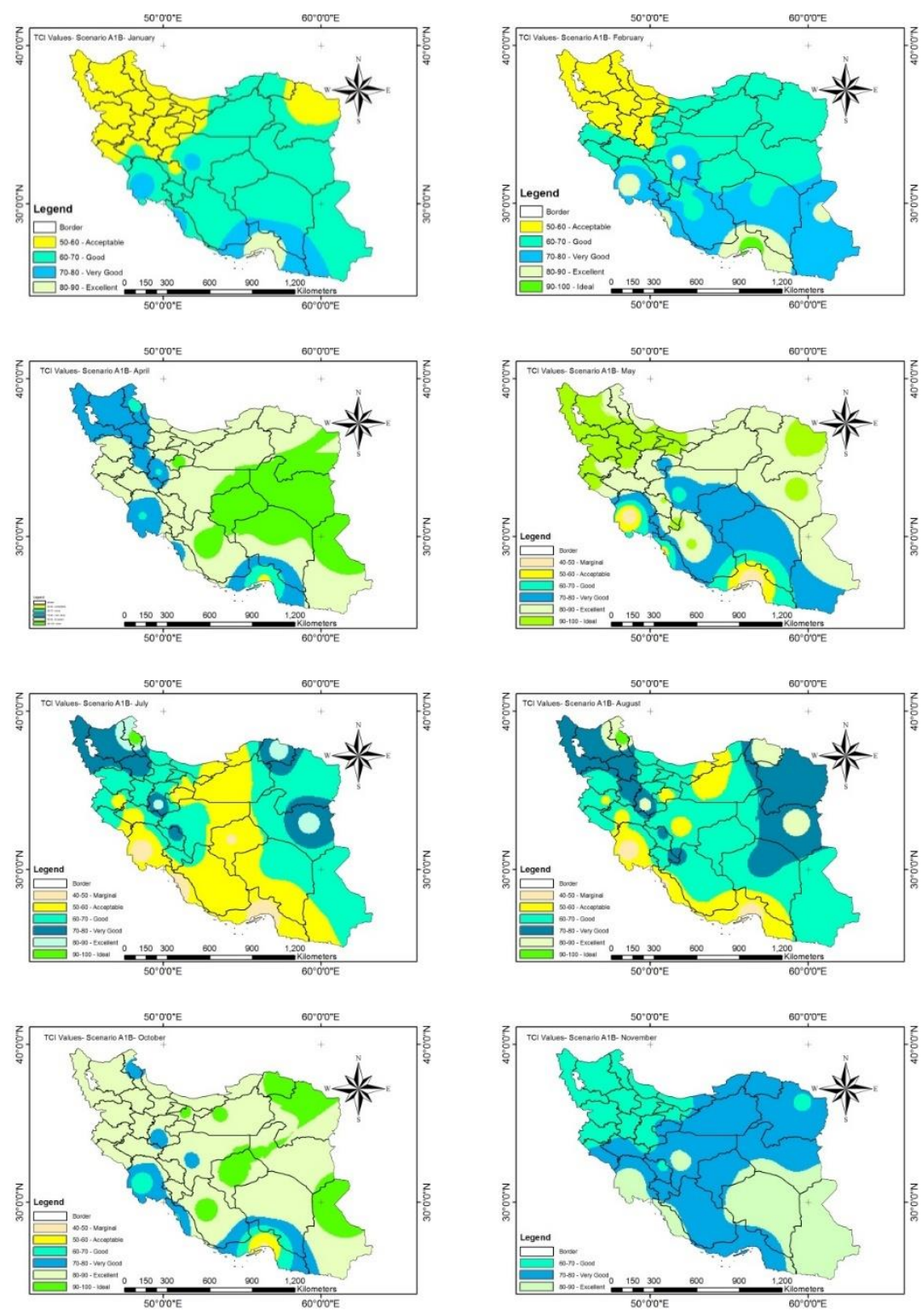

area). The southern part of Iran (about 38.6\% of Iran's area) such as southern part of Isfahan and South Khorasan, Yazd, Kerman, Sistan and Baluchestan, Hormozgan, Fars, Bushehr, and parts of Khuzestan will have experienced "Excellent" climatic condition. Also, climatic conditions in April divided into 5 classes such as "Ideal", "Excellent", "Very Good", "Good", and "Acceptable".
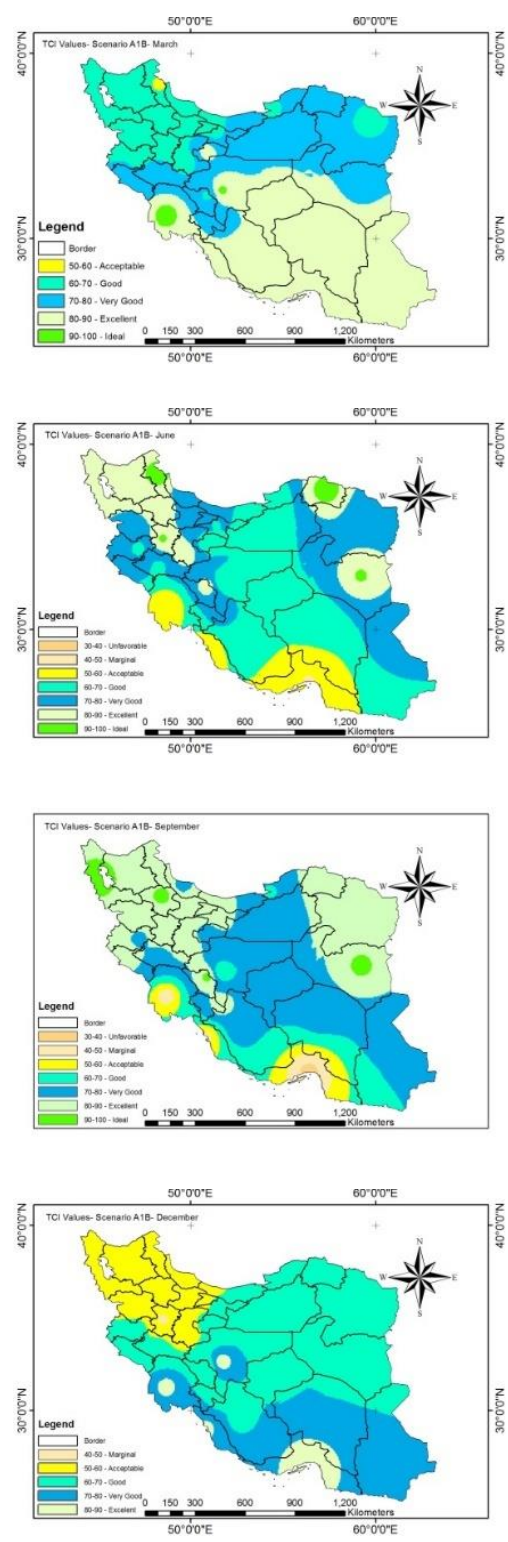

Figure 5. Spatial distribution of Tourism Climate Index over the study area under scenario of A1B in the future period (2016-2045)

Spatial distribution of $\mathrm{TCl}$ Index in April shows that $25.5 \%$ of Iran's area such as Qom, south of Razavi Khorasan, South Khorasan, Yazd, northwest of Fars, north of Kerman and north of Sistan and Baluchestan will have Ideal climatic conditions for tourism activities. Based on Figure 5, the climatic condition gets better from south to north and west to east. Owing to climate change impacts on climatic variables, the climatic condition gets better for tourism activities. In May, when the weather starts getting warm, the spatial distribution of $\mathrm{TCl}$ shows that the best destinations are northwestern parts of the country and
Razavi and South Khorasan (11.89\% total area of Iran). Next the coast of the Caspian Sea (including the Gilan, Ardabil, Golestan, and parts of Mazandaran province), Semnan, North Khorasan, Razavi and South Khorasan, northern parts of Sistan and Baluchestan, Markazi, Chaharmahal and Bakhtiari, and Lorestan will have experienced "Excellent" climate condition. From center to the south of Iran, TCl scores get smaller so that the Hormozgan and Khuzestan provinces will have experienced "Marginal" climate condition. In the month of June, $12.1 \%$ of Iran's area will have experienced "Acceptable" conditions, especially in 
Khuzestan, Bushehr, Fars, Hormozgan and Kerman provinces under the A1B scenario. The coastal area of Hormozgan (about $0.0908 \%$ ) will have experienced "Marginal", "Unfavorable" conditions. Other parts of the country have "Good" (33.18\%), "Very Good" (41.07\%), "Excellent" (12.54\%), and "Ideal" (1.02\%) conditions. So that the impact of climate change on $\mathrm{TCl}$ index is positive and causes to increase the appropriate area for tourism activities. In July under the A1B scenario, climatic conditions include 6 classes such as "Ideal", "Excellent", "Very Good", "Acceptable", and "Marginal". The corresponding area of each class is $0.2,2.01,11.99,47.33$, 35.5 , and $2.96 \%$ of Total Iran's area, respectively. In this month, the eastern parts of the country (east of Golestan and Semnan, North Khorasan, Razavi Khorasan, South Khorasan, east of Kerman and parts of Sistan and Baluchestan) have appropriate conditions for outdoor activities. In this time western provinces (West and East Azarbayjan, Ardabil, Rasht, Kermanshah, Ilam, Zanjan, Markazi, Qazvin, west of Isfahan, Chahrmahal and Bakhtiari have the same condition. Based on the results of $A 1 B$ scenario, August has conformity with the middle of the summer season in Iran. In this time southern area such as Hormozgan, south of Fars, Bushehr, Khuzestan, and parts of the Northern Province (Semnan, Mazandaran, and Golestan) have "acceptable" climatic condition. Moreover, $1.31 \%$ of total Iran's area (located in Hormozgan, and
Khuzestan province) has "Marginal" condition. Other parts of Iran (about 77.81\%) have "Ideal", "Excellent", "Very Good", and "Good" condition for traveling and leisure time. With occurrence of Climate change, the class of "Unfavorable" was eliminated and the areas of "Ideal", "Excellent", and "Very Good" classes were increased. In September, owing to the elimination of "Very unfavorable" and "Extremely unfavorable" classes, the number of classes reduced from 9 to 7 . Under the A1B scenario, all provinces with $93.61 \%$ of Iran's area have the appropriate condition for traveling and outdoor activities. Among all provinces, Khuzestan, Busher, southeast of Fars, Hormozgan, and south of Kerman have "Acceptable", "Marginal", and "Unfavorable" conditions (about 6.4\% total Iran's area). In October, "Unfavorable" class was eliminated and the class of "Excellent" has the largest covered area (about 66.9\% total Iran's area). In this time, south coastal areas have "Very Good", "Good", and "Acceptable" conditions with corresponding area $15.5,2.81$, and $1 \%$, respectively. In November, Iran's climatic conditions were divided into 3 classes such as "Excellent", "Very Good", and "Good". The northwestern parts of the country (West and East Azerbaijan, Ardabil, Zanjan, Kurdistan, Qazvin, Qom, Markazi, and Hamedan) with $27 \%$ of Iran's area will have experienced "Excellent" climate condition. The central parts of the country with $55 \%$ of Iran's area will have experienced "Very Good".

Table 4. The linear and non-linear equations of $\mathrm{TCl}$ for each month ( $\left.\mathrm{TCl}_{\text {month }}\right)$

\begin{tabular}{|c|c|c|}
\hline Month & Equation & Equation name \\
\hline \multirow{4}{*}{ January } & $\mathrm{TCl}=(31.611(\mathrm{Y})+6.815(\mathrm{X})-0.321(\mathrm{Z})) /(1.166(\mathrm{Y})+0.023(\mathrm{X})-0.003(\mathrm{Z})-16.643)$ & Linear regression (Baggio and Klobas 2011) \\
\hline & $\mathrm{TCl}=(31.611(\mathrm{Y})+6.815(\mathrm{X})-0.321(\mathrm{Z})) /(1.166(\mathrm{Y})+0.023(\mathrm{X})-0.003(\mathrm{Z})-16.643)$ & Nonlinear regression (a) \\
\hline & $\mathrm{TCl}=(522989.695-2808.371(\mathrm{X})-0.218(\mathrm{Z})-25966.820(\mathrm{Y})-$ & Nonlinear regression- Ratio of Quadratics (b) \\
\hline & $\left.0.005(\mathrm{Z})^{2}+62.312(\mathrm{X})^{2}+379.553(\mathrm{Y})^{2}\right) /\left(0.577(\mathrm{Y})^{2}+0.436(\mathrm{X})^{2}\right)$ & (Moffat et al., 2007) \\
\hline \multirow{2}{*}{ February } & $\mathrm{TCl}=-1.902(\mathrm{Y})+0.308(\mathrm{X})-0.011(\mathrm{Z})+119.615$ & Linear regression \\
\hline & $\mathrm{TCl}=-13.782(\mathrm{Y})-0.730(\mathrm{X})-0.003(\mathrm{Z})+0.172(\mathrm{Y})^{2}+0.01(\mathrm{X})^{2}-2.776 \mathrm{E}-6(\mathrm{Z})^{2}+344.240$ & Nonlinear regression-Quadratic \\
\hline \multirow{2}{*}{ March } & $\mathrm{TCl}=-1.907(\mathrm{Y})+0.392(\mathrm{X})-0.01(\mathrm{Z})+118.812$ & Linear regression \\
\hline & $\mathrm{TCl}=(10.029(\mathrm{Y})+20.631(\mathrm{X})-0.421(\mathrm{Z})) /(0.633(\mathrm{Y})+0.235(\mathrm{X})-0.005(\mathrm{Z})-13.907$ & Nonlinear regression \\
\hline \multirow[b]{2}{*}{ April } & $\mathrm{TCl}=0.831(\mathrm{X})-0.003(\mathrm{Z})+36.907$ & Linear regression \\
\hline & $\begin{array}{c}\mathrm{TCl}=(683167.043-13087.440(\mathrm{X})+98.629(\mathrm{Z})-25697.725(\mathrm{Y})- \\
\left.0.055(\mathrm{Z})^{2}+449.566(\mathrm{X})^{2}+48.806(\mathrm{Y})^{2}\right) /\left(-3.442(\mathrm{Y})^{2}+3.462(\mathrm{X})^{2}\right)\end{array}$ & Nonlinear regression- Ratio of Quadratics \\
\hline \multirow{3}{*}{ May } & $\mathrm{TCl}=1.509(\mathrm{Y})+0.378(\mathrm{X})+0.011(\mathrm{Z})-1.272$ & Linear regression \\
\hline & $\begin{array}{l}\mathrm{TCl}=(-745314.203-4816.605(\mathrm{X})+234.750(\mathrm{Z})+28838.05(\mathrm{Y})- \\
\left.0.059(\mathrm{Z})^{2}+85.230(\mathrm{X})^{2}+479.639(\mathrm{Y})^{2}\right) /\left(9.226(\mathrm{Y})^{2}+0.183(\mathrm{X})^{2}\right)\end{array}$ & Nonlinear regression- Ratio of Quadratics (a) \\
\hline & $\mathrm{TCl}=(122.317(\mathrm{Y})-35.016(\mathrm{X})+1.728(\mathrm{Z})) /(0.83(\mathrm{Y})-0.625(\mathrm{X})+0.015(\mathrm{Z})+38.001)$ & Nonlinear regression (b) \\
\hline \multirow[b]{2}{*}{ June } & $\mathrm{TCl}=2.285(\mathrm{Y})+0.017(\mathrm{Z})-21.071$ & Linear regression \\
\hline & $\mathrm{TCl}=(20468.915(\mathrm{Y})-2652.472(\mathrm{X})+169.236(\mathrm{Z})) /(\mathrm{Y}+\mathrm{X}+9804.451)$ & $\begin{array}{l}\text { Nonlinear regression- Michaelis Menten } \\
\text { (Moffat et al., 2007) }\end{array}$ \\
\hline \multirow{2}{*}{ July } & $\mathrm{TCl}=1.876(\mathrm{Y})+0.017(\mathrm{Z})-15.267$ & Linear regression \\
\hline & $\mathrm{TCl}=(5004.279(\mathrm{Y})-603.208(\mathrm{X})+49.822(\mathrm{Z})) /(\mathrm{Y}+\mathrm{X}+2783.549)$ & Nonlinear regression- Michaelis Menten \\
\hline \multirow{2}{*}{ August } & $\mathrm{TCl}=1.572(\mathrm{Y})+0.018(\mathrm{Z})-4.904$ & Linear regression \\
\hline & $\mathrm{TCl}=(3.594 \mathrm{E} 8(\mathrm{Y})-8587381.781(\mathrm{X})+4490069.929(\mathrm{Z})) /(\mathrm{Y}+\mathrm{X}+2.427 \mathrm{E} 8)$ & Nonlinear regression- Michaelis Menten \\
\hline \multirow{2}{*}{ September } & $\mathrm{TCl}=1.670(\mathrm{Y})+0.018(\mathrm{Z})+2.321$ & Linear regression \\
\hline & $\mathrm{TCl}=(169.686(\mathrm{Y})+12.452(\mathrm{X})+4.707(\mathrm{Z})) /(-0.357(\mathrm{Y})+0.02(\mathrm{X})+0.028(\mathrm{Z})+123.983)$ & Nonlinear regression \\
\hline \multirow[b]{2}{*}{ October } & $\mathrm{TCl}=0.395(\mathrm{X})+0.009(\mathrm{Z})+51.082$ & Linear regression \\
\hline & $\begin{array}{c}\mathrm{TCl}=\left(-10153.462(\mathrm{X})+32752.823(\mathrm{Y})+84.550(\mathrm{Z})-10153.462(\mathrm{Z})^{2}+137.989(\mathrm{X})^{2}-305.236\right. \\
\left.(\mathrm{Y})^{2}-373682.715\right) /\left(2.306(\mathrm{Y})^{2}+0.25(\mathrm{X})^{2}\right)\end{array}$ & Nonlinear regression- Ratio of Quadratics \\
\hline \multirow{2}{*}{ November } & $\mathrm{TCl}=-1.892(\mathrm{Y})+0.433(\mathrm{X})-0.0061(\mathrm{Z})+118.244$ & Linear regression \\
\hline & $\mathrm{TCl}=(42.286(\mathrm{Y})+42.287(\mathrm{X})-1.049(\mathrm{Z})) /(1.597(\mathrm{Y})+0.404(\mathrm{X})-0.012(\mathrm{Z})-26.710)$ & Nonlinear regression \\
\hline \multirow{2}{*}{ December } & $\mathrm{TCl}=-1.808(\mathrm{Y})+0.356(\mathrm{X})-0.0084(\mathrm{Z})+110.223$ & Linear regression \\
\hline & $\mathrm{TCl}=-14.742(\mathrm{Y})-1.708(\mathrm{X})+0.188(\mathrm{Y})^{2}+0.021(\mathrm{X})^{2}-2.411 \mathrm{E}-6(\mathrm{Z})^{2}+375.851$ & Nonlinear regression- Quadratic \\
\hline
\end{tabular}

November is the best month for traveling to Iran. All destinations have an appropriate climatic condition at this time. In December, comparison of baseline and future periods showed that the class of "Unfavorable" was eliminated and $15.6 \%$ of Iran's area located in northwestern parts will have experienced "Acceptable" climatic conditions. While the $53.46 \%$ of Iran's area located in northern, western, central, and eastern parts of the 
country were situated in "Good" class. Southern parts of Iran include Khuzestan, Sistan and Baluchestan, Bushehr, south of Fars and Kerman has "Very Good" conditions. Also, the southern coasts of Iran located in Hormozgan province have the most appropriate conditions at this time.

\section{Regression models}

The regression models were investigated by using three geographic variables (latitude $(Y)$, longitude $(X)$, elevation above the sea level (Z)) as the independent variable and calculated monthly $\mathrm{TCl}$ values as the dependent variable. The linear and non-linear regression models are presented in Table 4. Also, the scatter plot of monthly $\mathrm{TCl}$ values was shown in Figure 6. The root mean square error (RMSE), mean error (ME), mean absolute relative error (MARE) and coefficient of determination $\left(R^{2}\right)$ were used to compare the accuracy of models that their results are shown in Table 4. The standard errors rates of the parameter estimate in non-linear models are high except for February and December. However, the differences in the statistical performance measures of the linear and non-linear models for each month in Table 4 shows that non-linear models worked more accurate. For instance, the non-linear model for April month explained $56 \%$ of the variation in $\mathrm{TCl}$ values while the linear model explained for only $18 \%$. All regression coefficients of the linear model for April month have been significant at the $95 \%$ confidence level except for latitude. This suggests that latitude is not important to $\mathrm{TCl}$ modeling for this month. However, all coefficients of the model for January, February, March, May, November and December months have been significant at the $95 \%$ confidence level. According to Table 5, the corresponding $\mathrm{p}$-values for $\mathrm{F}$-test indicate the linear regression models are significant at the $95 \%$ confidence level. Figure 6 compares the simulated $\mathrm{TCl}$ using the regression models with the baseline $\mathrm{TCl}$ values result from the main model (Mieczkowski, 1985) for each month. The good performance of the multiple regression models indicates that they can be used in the practical applications.

Table 5. Model errors and statistical significance

\begin{tabular}{|c|c|c|c|c|c|c|c|c|}
\hline $\begin{array}{c}\text { Dependent } \\
\text { variable }\end{array}$ & $\begin{array}{c}\text { Independent } \\
\text { variables }\end{array}$ & $\begin{array}{c}\text { p-value for t- } \\
\text { test }\end{array}$ & $\begin{array}{c}\text { p-value for } \\
\text { F-test }\end{array}$ & model & $\mathbf{R}^{2}$ & RMSE & ME & MARE \\
\hline \multirow{3}{*}{$\mathrm{TCl}_{\text {Jan }}$} & Lat. & 0 & \multirow{3}{*}{0} & Linear & 0.501 & 9.701 & $1.9 \times 10^{-7}$ & 0.132 \\
\hline & Long. & 0.007 & & Nonlinear (a) & 0.571 & 8.363 & 0.015 & 0.125 \\
\hline & Elev. & 0 & & Nonlinear (b) & 0.658 & 8.123 & 0.002 & 0.116 \\
\hline \multirow{3}{*}{$\mathrm{TCl}_{\mathrm{Feb}}$} & Lat. & 0 & \multirow{3}{*}{0} & Linear & 0.683 & 8.079 & \multirow{3}{*}{$6.5 \times 10^{-8}$} & 0.114 \\
\hline & Long. & 0.013 & & Nonlinoar & \multirow{2}{*}{0.786} & \multirow{2}{*}{6.638} & & 0.107 \\
\hline & Elev. & 0 & & Nonlınear & & & & 0.150 \\
\hline \multirow{3}{*}{$\mathrm{TCl}_{\mathrm{Mar}}$} & Lat. & 0 & \multirow{3}{*}{0} & Linear & 0.554 & 10.263 & $2.6 \times 10^{-7}$ & 0.150 \\
\hline & Long. & 0.013 & & Nonlinoar & 0606 & 0614 & 0141 & ) \\
\hline & Elev. & 0 & & Nonlınear & 0.606 & 9.644 & 0.144 & 0.006 \\
\hline \multirow{2}{*}{$\mathrm{TCl}_{\mathrm{Apr}}$} & Long. & 0 & \multirow{2}{*}{0.027} & Linear & 0.181 & 11.037 & $1.3 \times 10^{-7}$ & 0.183 \\
\hline & Elev. & 0.027 & & Nonlinear & 0.56 & 8.090 & 0.0001 & 0.122 \\
\hline \multirow{3}{*}{$\mathrm{TCl}_{\text {May }}$} & Lat. & 0 & \multirow{3}{*}{0} & Linear & 0.498 & 10.288 & $3.9 \times 10^{-7}$ & 0.161 \\
\hline & Long. & 0.17 & & Nonlinear (a) & 0.626 & 8.884 & 0.0003 & 0.139 \\
\hline & Elev. & 0 & & Nonlinear (b) & 0.592 & 9.270 & 0.009 & 0.144 \\
\hline \multirow{2}{*}{$\mathrm{TCl}_{\text {Jun }}$} & Lat. & 0 & \multirow{2}{*}{0} & Linear & 0.777 & 8.491 & $2.6 \times 10^{-7}$ & 0.119 \\
\hline & Elev. & 0 & & Nonlinear & 0.78 & 8.345 & 0.0005 & 0.112 \\
\hline \multirow{2}{*}{$\mathrm{TCl}_{\mathrm{sul}}$} & Lat. & 0 & \multirow{2}{*}{0} & Linear & 0.802 & 7.486 & $2.5 \times 10^{-7}$ & 0.111 \\
\hline & Elev. & 0 & & Nonlinear & 0.806 & 6.312 & 0.0023 & 0.106 \\
\hline \multirow{2}{*}{$\mathrm{TCl}_{\text {Aug }}$} & Lat. & 0 & \multirow{2}{*}{0} & Linear & 0.822 & 7.070 & 0 & 0.100 \\
\hline & Elev. & 0 & & Nonlinear & 0.821 & 6.987 & 0.0002 & 0.087 \\
\hline \multirow{2}{*}{$\mathrm{TCl}_{\text {sep }}$} & Lat. & 0 & \multirow{2}{*}{0} & Linear & 0.778 & 8.141 & $1.9 \times 10^{-7}$ & 0.106 \\
\hline & Elev. & 0 & & Nonlinear & 0.798 & 7.766 & 0.021 & 0.100 \\
\hline \multirow{2}{*}{$\mathrm{TCl}_{\text {oct }}$} & Long. & 0.004 & \multirow{2}{*}{0} & Linear & 0.338 & 9.553 & $2.6 \times 10^{-7}$ & 0.150 \\
\hline & Elev. & 0 & & Nonlinear & 0.712 & 8.147 & 0.0003 & 0.116 \\
\hline \multirow{3}{*}{$\mathrm{TCl}_{\text {Nov }}$} & Lat. & 0 & \multirow{3}{*}{0.004} & Linear & 0.526 & 9.349 & $6.5 \times 10^{-8}$ & 0.138 \\
\hline & Long. & 0.003 & & & & & & 127 \\
\hline & Elev. & 0 & & Nonlinear & 0.586 & 8.739 & 0.005 & 0.127 \\
\hline \multirow[b]{2}{*}{$\mathrm{TCl}_{\text {Dec }}$} & Lat. & 0 & \multirow[b]{2}{*}{0} & Linear & 0.588 & 8.710 & $6.5 \times 10^{-8}$ & 0.118 \\
\hline & Long. & 0.008 & & Nonlinear & 0.745 & 6.861 & $6.5 \times 10^{-5}$ & 0.109 \\
\hline
\end{tabular}

\section{Conclusion}

Climatic and geographical analyses are required for tourism and tourism investors. The impact of weather information can also be assessed from the aspect of human biometeorology. Tourism Climate Index (TCI) is a useful index, for it uses climatic variables in relation to biometeorological studies on a single index that is promptly explainable by the traveler. According to studies included in this article, the results can be classified into three parts. At first, a user-friendly and multi-platform software was developed in JAVA language to calculate and present Iran's Tourism Climate Indices. The proposed program called ITCIC, allows determination of $\mathrm{TCl}$ of Iran's synoptic weather stations according to the months of the year. Using ITCIC allows easy calculation of $\mathrm{TCl}$ with a large number of climatic data and captures the changing patterns of $\mathrm{TCl}$ during the year at each of the stations. Different climate comfort zones from the viewpoint of tourism have been identified by using ArcGIS software. The $\mathrm{TCl}$ provides a useful measure of climate for the average 
tourist and may be used to evaluate the appropriateness of sub-index rating systems and weightings in the $\mathrm{TCl}$ against stated visitor preferences. Furthermore, additional validations are needed in order to further assess the value of weather and climate in tourism research, especially for agritourism and ecotourism sectors. This study focused on the impacts of climate change on human comfort by using Mieczkowski's tourism climate index (TCl) and the LARSWG statistical downscaling method under the $A 1 B$ scenario. For this purpose, long-term data of 153 synoptic meteorological stations were used in the period of (19852015) and TCl values were predicted for the period of 20162045. The spatial variation of tourism climate index was investigated for baseline and future period. Finally, the monthly $\mathrm{TCl}$ values were simulated using the linear and non-linear regression models with the baseline geographical coordinate variables as inputs. The multiple linear regression models all showed that latitude was the most important and significant factor correlated with the monthly $\mathrm{TCl}$ except for April and October months, while elevation factor had the lowest correlation with $\mathrm{TCl}$, inversely. Comparison of simulated $\mathrm{TCl}$ values by using regression models and baseline $\mathrm{TCl}$ values showed that $\mathrm{a}$ good accuracy of $\mathrm{TCl}$ prediction. Thus, it is assumed that there are other unknown factors influencing $\mathrm{TCl}$ values that were not taken into account in the analyses and they have the potential for explaining more variations in $\mathrm{TCl}$ values.
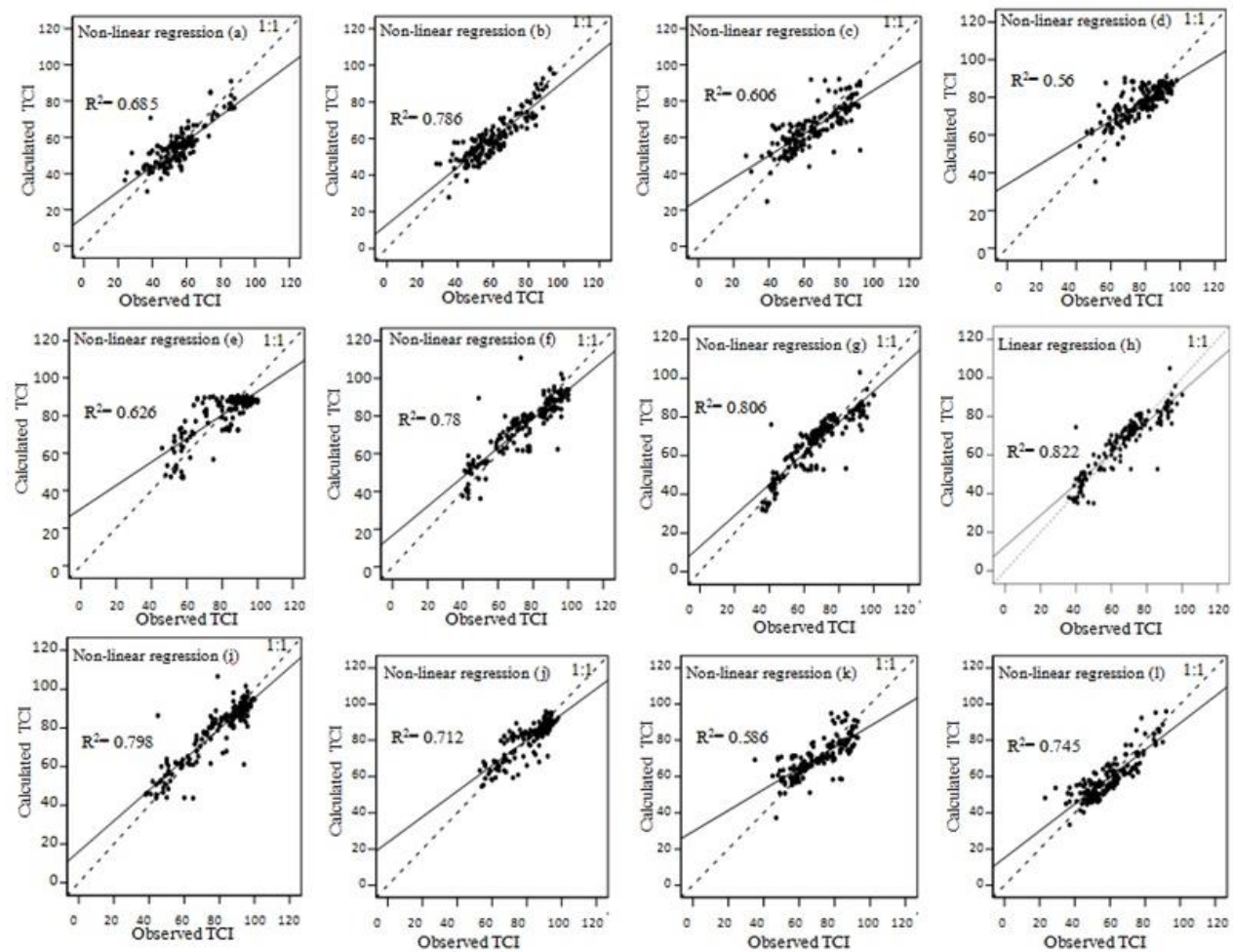

Figure 6. Scatter plot of the baseline TCI values result from the main model (Mieczkowski's, 1985) vs. calculated TCI values result from the linear and non-linear models in January (a), February (b), March (c), April (d), May (e), June (f), July (g), August (h), September (i), October (j), November (k) and December (I) across Iran

\section{Acknowledgment}

This paper has been carried out within the framework of research project No. 88001819 financed by the Iran National Science Foundation (INSF). The authors thank the INSF for supporting of this project.

\section{References}

Amelung B. and Nicholls S. (2014), Implications of climate change for tourism in Australia, J Tour Manage, 41, 228- 244.

Amelung B. and Vine D. (2006) Mediterranean tourism, exploring the future with the tourism climate index, J Sustain Tour, 14, 349-366. doi: 10.2167/jost549.0

Amelung B., Nicholls S. and Viner D. (2007), Implications of Global Climate Change for Tourism Flows and Seasonality, J Travel Res, 45(3), 285-296. doi, https,//doi.org/10.1177/0047287506295937

Anđelković G., Pavlović S., Đurđić S., Belij M. and Stojković S. (2016), Tourism climate comfort index (TCCI) - an attempt to evaluate the climate comfort for tourism purposes: the example of Serbia, Global NEST Journal, 18(3), 482-493.

ASHRAE. (1972), ASHRAE handbook of fundamentals American Society of Heating. Refrigeration and Air-Conditioning Engineers, New York, 688 p.

Baggio R. and Klobas J. (2011), Quantitative Methods in Tourism, Channel View, Bristol.

Becker S. (2000), Bioclimatological rating of cities and resorts in South Africa according to the climate index, Int J Climatol, 20, 1403-1414.

Bigano A., Hamilton J.M. and Tol R.S.J. (2006), The impact of climate on holiday destination choice, Clim Chang, 76, 389-406. doi, 10.1007/s10584-005-9015-0

Bosco L.C., Bergamaschi H., Cardoso L.S., de Paula V.A., Marodin G.A. and Nachtigall G.R. (2015), Apple production and quality when cultivated under anti-hail cover in Southern Brazil, Int J Biometeorol, 59, 773-782. doi, 10.1007/s00484-014-0893-6 
Cohen P., Potchter O. and Matzarakis A., (2013), Human thermal perception of coastal Mediterranean outdoor urban environments, Appl Geogr, 37, 1-10.

Crowe R.B. (1976), A climatic classification of the Northwest Territories for recreation and tourism, Environment Canada, Toronto.

Crowe R.B., McKay G.A. and Baker W.M. (1973), The tourist and outdoor recreation climate of Ontario, vol 1, objectives and definitions of season. Report Number REC-1-73, Atmospheric Environment Service, Environment Canada, Toronto, Canada.

De Freitas C.R. (1990), Recreation climate assessment, Int J Climatol, 10, 89-103. doi, 10.1002/joc.3370100110

De Freitas C.R., Scott D. and McBoyle G. (2008), A second generation climate index for tourism (CIT), specification and verification, Int J Biometeorol, 52, 399-407. doi: 10.1007/s00484-007-0134-3

Esmaili R. and Fallah Ghalhari Gh. (2014), An Assessment of Bioclimatic Conditions for Tourists-A Case Study of Mashhad, Iran, Atm and Clim Sci, 4, 137-146.

Farajzadeh H. and Matzarakis A. (2009), Quantification of climate for tourism in the northwest of Iran, Meteorol Appl, 16, 545-555. doi, 10.1002/met.155

Gandomkar A. and Mohseni N. (2011). Analysis and Estimate Tourism Climate Index of Mazandaran Province, Using TCI Model. $2^{\text {nd }}$ International Conference on Business, Economics and Tourism Management, IPEDR vol. 24, IACSIT Press, Singapore.

Gomez Martin M.B. (2004), An evaluation of the tourist potential of the climate in Catalonia (Spain), a regional study, Geogr Ann, 86A, 249-264.

Hamilton J. and Lau M. (2005), The role of climate information in tourist destination choice decision making. In, Gössling S, Hall CM (eds.) Tourism, recreation and climate change, Routledge, London, pp 229-250.

Hamilton J.M., Maddison D.J. and Tol R.S.J. (2003), Climate change and international tourism, A simulation study. Working Paper FNU-31, Research Unit Sustainability and Global Change, Centre for Marine and Climate Research, University of Hamburg.

Hamilton J.M., Maddison D.J. and Tol R.S.J. (2004), Effects of climate change on international tourism, Clim res, 29(3), 245-254.

Hamilton J.M., Maddison D.J. and Tol R.S.J. (2005), Climate change and international tourism: A simulation study, Glob Environ Chan, 15(3), 253-266.

Khalili A. (1997), Integrated water plan of Iran. Vol. 4, Meteorological studies, Ministry of Energy, Iran

Lin T.P. and Matzarakis A. (2008), Tourism climate and thermal comfort in SunMoon Lake, Taiwan, Int J Biometeorol, 52, 281-290.

Lise W. and Tol R.S.J. (2002), Impact of climate on tourist demand, Clim Chang, 55, 429-449.

Liu Y. (2014), A regression model for smoke plume rise of prescribed fires using meteorological conditions, J Appl Meteor Climatol, 53, 1961-1975, doi, 10.1175/JAMC-D-130114.1

Maddison D. (2001), In search of warmer climates? The impact of climate change on flows of British tourists, Clim Chang, 49, 193-208.

Matzarakis A. (2002), Examples of climate and tourism research for tourism demands. 15th Conference on Biometeorology and Aerobiology joint with the International Congress on Biometeorology, 27 October- 1 November 2002, Kansas City, Missouri, 391-392.

Matzarakis A. (2007), Assessment method for climate and tourism based on daily data. In Developments in Tourism Climatology, Matzarakis A, de Freitas CR, Scott D (eds.), Commission on Climate, Tourism and Recreation, International Society of Biometeorology, Freiburg, pp 52-58.

Matzarakis A., Mayer H. and Iziomon M. (1999), Heat stress in Greece. Applications of a universal thermal index, physiological equivalent temperature, Int J Biometeorol, 43, 76-84. doi, 10.1007/s004840050119

Mieczkowski Z. (1985), The tourism climatic index, a method of evaluating world climates for tourism, Can Geogr, 29, 220-233.

Moffat A.M., Papale D., Reichstein M., Hollinger Y., Richardson A.D., Barr A.G., Beckstein C., Braswell H., Churkina G., Desai A.R., Falge E., Gove J.H., Heimann M., Hui D., Jarvis A.J., Kattge J., Noormets A. and Stauch V.J. (2007), Comprehensive comparison of gap-filling techniques for eddy covariance net carbon fluxes, Agric For Meteorol, 147,209-232.

Morgan R., Gatell E., Junyent R., Micallef A., Özhan E., and Williams A. (2000), An improved user-based beach climate index, J Coast Conserv, 6, 41-50.

Morris K.I., Chan A., Morris K.J.K., Ooi M.C.G., Oozeer M.Y., Abakr Y.A., Nadzir M.S.M., Mohammed I.Y. and Al-Qrimli H.F. (2017), Impact of urbanization level on the interactions of urban area, the urban climate, and human thermal comfort, Appl Geogr, 79, 50-72.

Nasirihendkhaleh E., Zahraei A., Ghadiri H. and Komasi H. (2014), Zoning evaluation of Eco-Touristic potentials of bio-climatic comfortability in the province of Fars, using Geographical information system (GIS), Int J Advanced Res, 2, 768-776.

Rahimi J., Khalili A. and Ebrahimpour M. (2013), Spatial changes of Extended De Martonne climatic zones affected by climate change in Iran, Theor App/ Climatol, 112, 409-418.

Scott D., and McBoyle G. (2001), Using a 'tourism climate index' to examine the implications of climate change for climate as a natural resource for tourism. In, Matzarakis A, de Frietas CR (eds.) Proceedings of the First International Workshop on Climate, Tourism and Recreation. International Society of Biometeorology, Commission on Climate, Tourism and Recreation, Halkidi, Greece, pp. 69-98.

Scott D., McBoyle G. and Mills B. (2003), Climate change and the skiing industry in Southern Ontario (Canada), exploring the importance of snowmaking as a technical adaptation, Clim Res, 23, 171-181.

Scott D., McBoyle G. and Schwartzentruber M. (2004), Climate change and the distribution of climatic resources for tourism in North America, Clim Res, 27(2), 105-117.

Setegn S.G., Rayner D., Melesse A.M., Dargahi B., Srinivasan R. and Wörman A. (2011), Climate change impact on agricultural water resources variability in the Northern Highlands of Ethiopia. In, Melesse A.M. (eds), Nile River Basin, 241-265.

Yazdanpanah H., Barghi H. and Esmaili A. (2016), Effect of climate change impact on tourism, A study on climate comfort of Zayandehroud River route from 2014 to 2039, Tour Manag Perspectives, 17, 82-89. 